\title{
Blodprøver og piller er også omsorg
}

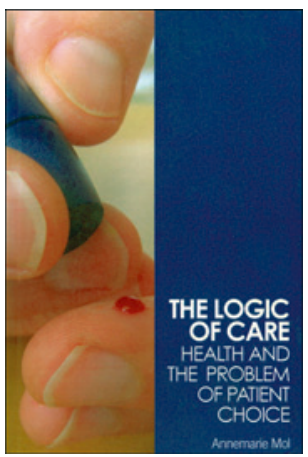

Annemarie Mol

\section{The logic of care}

Health and the problem of patient choice.

144 s. New York: Routledge, 2008. Pris GBP 22

ISBN 978-0-415-45343-1

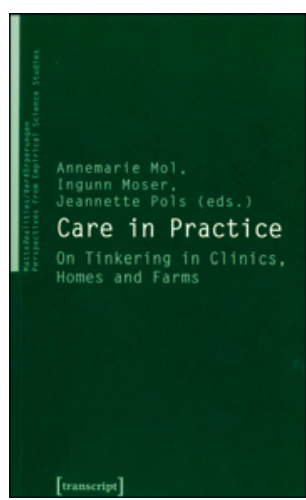

Annemarie Mol, Ingunn Moser

Jeanette Pols, red.

Care in practice

On tinkering in clinics, homes and farms. 326 s. Bielefeld: Transcript Verlag, 2010

Pris EUR 36

ISBN 978-3-8376-1447-3

For noen år siden var en venninne av meg hos kardiolog fordi hun hadde merket brystsmerter.
Det var hjertesykdom i familien, og hun var fryktelig engstelig for at turen nå var kommet til henne.

Arbeids-EKG var imidlertid negativ, og kardiologen konkluderte med at hun hadde $70 \%$ sjanse for ikke å ha hjertesykdom. Han trodde nok hun skulle bli glad, og opplevde sikkert selv at han ga god informasjon i tråd med etablert evidens. For min venninne var det imidlertid totalt utilstrekkelig: For hva med $30 \%$ risiko for at det var hjertesykdom? Burde hun utredes mer? Hun var enda mer usikker etter timen enn før.

Kardiologens atferd er ikke enestående. I stadig større grad styres dagens medisinske behandling av det som Annemarie Mol i The logic of care kaller «valglogikken»: troen på at legen nøytralt skal legge fakta på bordet, mens pasienten skal ta stilling til det videre forløp.

\section{Pasienten skal velge}

Annemarie Mol (f. 1958) er en hollandsk filosof som har studert medisin, men gjør feltarbeid som en antropolog. Hun har vært en nøkkelfigur i de senere tiårenes vitenskaps- og teknologistudier, og hun har i hele yrkeskarrieren arbeidet med medisinsk relevante temaer. Mens hun gjorde feltarbeid i et sykehus i Nederland som forarbeid til sin mest kjente bok, The Body Multiple (1), begynte hun å interessere seg for omsorg og omsorgspraksiser. Siden har hun gitt ut to bøker - monografien The logic of care og artikkelsamlingen Care in Practice, som hun har redigert sammen med sine kolleger Jeanette Pols og Ingunn Moser.

Paternalismen som lå i det tradisjonelle lege-pasient-forholdet, som innebar at legen vet best og at pasienten må etterleve legens råd, har for lengst utspilt sin rolle. Evidens og valgfrihet er blitt de nye slagordene. Helseomsorgen er blitt en serie rettigheter og plikter, som kan styres gjennom kontrakter, f.eks. samtykke, slik samfunnsborgeren er underlagt rettigheter og plikter overfor staten. Man stiller rett og slett ikke spørsmål ved om det kun er et gode at pasientene får velge - mer valg er per definisjon bedre for pasienten. Legen skal nøytralt presentere de medisinske fakta for pasienten (jf. 70\% sjanse for å være frisk), og pasienten selv skal ta et informert valg om veien videre. Men blir vi bedre i stand til å vite hva vi velger, og hvorfor vi velger det, ved å gjøres til kunder og konsumenter slik dagens helsepolitikk ønsker? Mol mener bestemt nei.

Valglogikken henter sine forbilder fra to arenaer: den kapitalistiske logikk (pasienten som kunde) og politisk filosofi (pasienten som samfunnsborger). Valglogikken var ment å skulle gi pasientene makt, den skulle frigjøre dem fra legenes overformynderi. Men, hevder Mol, med valglogikken forsvant omsorgens spesifikke innhold.

Samfunnsborgermetaforen er dårlig og upassende. Samfunnsborgere blir per definisjon ikke plaget av sine skrantende kropper. Pasienter derimot har kropper som gir trøbbel og stadig forstyrrer. De oppsøker legen ikke fordi de kan velge, men fordi de ikke har noe valg. Med valg følger ansvar - valglogikken fører til at ansvaret for det som går galt, flyttes over til pasientene. I stedet for å være frigjørende blir valget snarere en tung tilleggsbelastning - slik det ble for min venninne etter at hun hadde vært hos kardiologen.

\section{Omsorg er samarbeid}

God omsorg for pasienter med kroniske sykdommer krever et pågående, uavsluttet, interaktivt arbeid som tar form som et samarbeid.

Omsorgslogikken innebærer ikke en nostalgisk tilbakevending til den passive pasienten og den paternalistiske legen. Derimot handler det om at leger og pasienter sammen - i praksis - forhandler om hva som er riktig behandlingsforløp - ut fra omstendighetene. Mol kaller det «shared doctoring». God behandling innebærer at legen og pasienten sammen prøver seg frem - på grunnlag ikke bare av tilgjengelig evidens, men også pasientens ressurser og behandlingens konsekvenser. Under omsorgslogikken er ikke legen en objektiv nøytral tilbyder av informasjon, og pasienten ikke den eneste som tar et valg. Omsorg gjøres ikke bare av helsepersonells varme hender og kjærlige blikk, omsorg inkluderer også de medisinene man bruker, og de undersøkelsesmetodene og den behandlingen man velger.

Omsorg under omsorgslogikken innebærer en erkjennelse av at pasientene også kan være eksperter. De kan vite mer enn sin fastlege om hva sykdommen deres innebærer, og de vet alltid best hva som fungerer for dem i deres hverdag. Valglogikken ser leger som roboter, som leverer behandling i henhold til hva konsument (pasient) og evidens krever.

Omsorgslogikken setter de faglige utøverne tilbake i sentrum. Den erkjenner at pasientens behov ikke alltid er klare, og at evidensen ofte er usikker. Den ideelle HbAlc-verdien kan ikke settes en gang for alle, men man må se an pasientens mulighet til å oppnå det innenfor gitte rammer. Mens valglogikken separerer fakta og verdier (legen skal bare komme med nøytrale fakta, pasienten skal stå for verdiene), vet legene som praktiserer god omsorg at de ikke kan skilles så lett i praksis. Innenfor omsorgslogikken handler det ikke primært om å lage bedre kart over virkeligheten, for eksempel angi presis prosentangivelse for sannsynlighet, men om, sammen med pasienten, å skape bedre måter å leve med og håndtere virkeligheten på. Det viktige er å prøve og feile til man kommer frem til et resultat som fungerer.

God omsorg innebærer en forhandling mellom forskjellige normer - av og til er det bedre å slå seg til ro med godt nok enn å streve etter mer. Det er ikke mulig å si hva som er bra, sånn helt generelt. Det er gjenstand for lokal forhandling og vil alltid variere. 


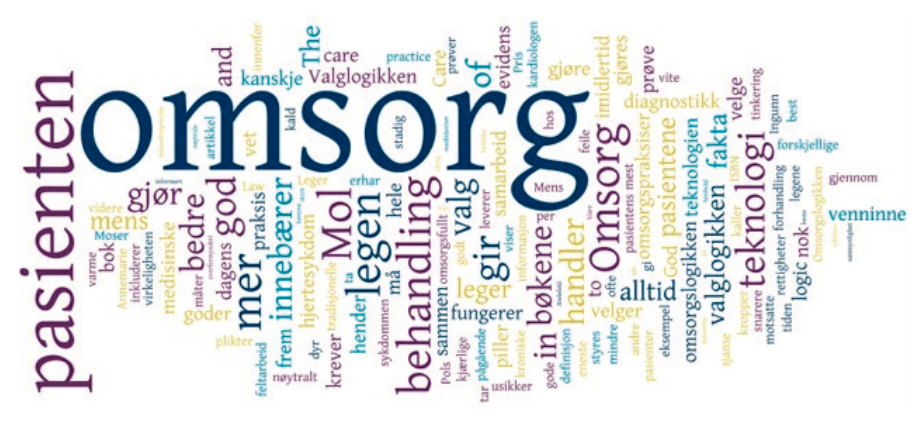

Man må ofte i praksis gjøre et kompromiss mellom forskjellige «goder» (rettferdighet, medlidenhet, sjenerøsitet, faglighet, tekniske goder, økonomiske goder). Omsorg handler om å gjøre sitt beste, om å lindre det som er tungt, om å fortsette å prøve selv om man feiler.

\section{Teknologi er også omsorg}

Care in practice er også en bok hvor man belyser ulike omsorgspraksiser og viser hvordan omsorg og teknologi ikke lar seg skille. Her er termometre og oksygenmasker, kjærlige hender, laboratorietester og endoskopier - samtidig.

Omsorg, sier redaktørene i det instruktive forordet, krever erfaring og ekspertise og er avhengig av intrikate ferdigheter. Teknologiske virkemidler er ikke det motsatte av omsorg, de er implisitte i alt omsorgsarbeid. Ifølge forfatterne kan ikke god omsorg defineres essensielt, snarere vil hva som er god omsorg være ulikt i hvert enkelt tilfelle, siden god omsorg består av å prøve seg frem, og lykkes eller feile, i den alltid komplekse hverdagen, eller med redaktørenes ord: «persistent tinkering in a world full of complex ambivalence and shifting tensions.»

Et eksempel: John Law beskriver i en artikkel den dramatiske historien om munn- og klovsyke i England på begynnelsen av 2000-tallet, da sykdommen raste gjennom landet, og veterinærer måtte avlive mengder med dyr. Law er opptatt av at omsorg ikke er hva vi umiddelbart tror. Selv avliving av dyr kan gjøres mer eller mindre omsorgsfullt, og selv i det mest kalkulerte kan det finnes omsorg.

I en annen artikkel handler det om telemedisin i Barcelona - en hjelpetjeneste for eldre som gir et lyttende øre til dem som trenger det. Artikkelen viser hvordan instrumentet ikke er omsorgsfullt i seg selv, men at omsorg skapes ved å jobbe med prosedyrer for hvordan teknikken fungerer og kreativt tilpasse det lokale forhold.
En tredje forfatter undersøker hvordan man prøver ut rullestoler i Frankrike i samarbeid med brukerne. Snarere enn å representere «kald» teknologi, er teknologi en aktiv deltaker i omsorgsarbeidet. En maskin kan være god til å gi omsorg, en datamaskin også.

Noen vil kanskje si: Greit nok, men det er da selvfølgelig? Dette gjør vi da hele tiden? På mange måter er det kanskje slik: Leger gir trøst, støtte, behandling og lindring - omsorg - hver eneste dag.

Men disse to bøkene gir et språk å snakke om omsorg i. For selv om leger gir omsorg hele tiden, snakker vi ikke om det. Det skrives artikler og kommentarer om behandling og om diagnostikk, men ikke om omsorg. Det er noe man bare gjør, mer eller mindre intuitivt. Og er ikke omsorg noe de andre gjør - de som jobber i omsorgsyrkene?

Det kanskje viktigste bidraget til disse bøkene er at de opphever det tradisjonelle skillet mellom teknologi og omsorg. Tidligere har det vært satt opp store motsetninger mellom omsorg og det som legene gjør, det som har med diagnostikk og behandling, teknologi og piller å gjøre. Leger er blitt fremstilt som teknokrater, mens alle andre helsearbeidere har tatt seg av «omsorgsbiten». Omsorg er blitt ensbetydende med kjærlighet og varme hender, mens teknologien, dens motpart, er kald og ufølsom $(2,3)$.

Omsorgen gir næring og beskytter, mens teknologien er instrumentell. Omsorg er kvinnelig, teknologien er mannlig. I begge disse bøkene understreker forfatterne imidlertid at omsorg ikke er det motsatte av diagnostikk og behandling, men at omsorg inkluderer både teknologi, blodprøver og piller. Så selv om bøkene handler om omsorgspraksiser innenfor alle helseprofesjoner, bør de leses spesielt godt av leger. Med sin kritikk av dagens nyliberalistiske forståelse av det medisinske møtet leverer de også gode argumenter til det pågående legeopprøret (4).

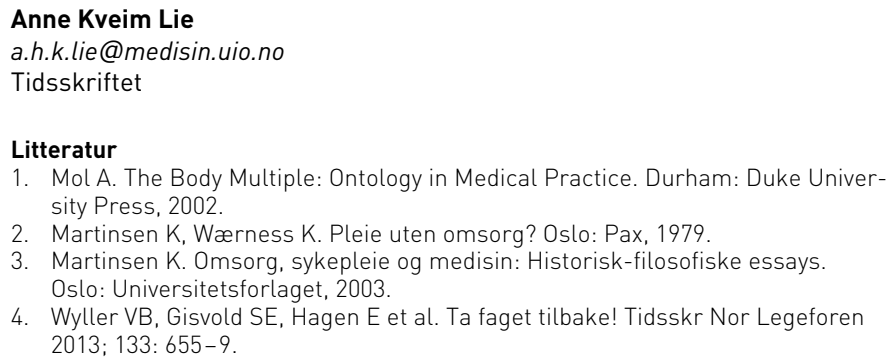

